\title{
Pour-on Suspension Dosage Form
}

National Cancer Institute

\section{Source}

National Cancer Institute. Pour-on Suspension Dosage Form. NCI Thesaurus. Code C149769.

Liquid preparation consisting of a suspension intended for pour-on use for the prevention and treatment of ectoparasitic and/or endoparasitic infestations of animals. Pour-on suspensions are applied in volumes that are usually greater than $5 \mathrm{~mL}$. 